\title{
ISKOLAÉRTÉKELÉS, SZAKFELÜGYELET HOLLANDIÁBAN
}

\author{
MAJOR ÉVA \\ az Eötvös Loránd Tudományegyetem Bölcsészettudományi Karának \\ egyetemi docense \\ major.eva@btk.elte.hu
}

\begin{abstract}
A tanulmány célja, hogy bemutassa a Holland Oktatási Felügyelöség (Inspectie van het Onderwijs) szerepét az iskolák és ezen keresztül az oktatás minöségének ellenörzésében. Az elmúlt húsz év holland oktatáspolitikájában két fontos irányvonal figyelhetö meg. Egyrészt egyre nagyobb az igény az oktatáshoz kapcsolódó teljesitményelvárások és sztenderdek meghatározására és érvényesitésére, másrészt az országos szabályozás csökkenésével az oktatási intézmények autonómiája és felelössége folyamatosan nö saját politikájuk és gyakorlatuk kialakitásában. Ezekhez a tendenciákhoz illeszkedik az Oktatási Felügyelöség szerepének változása is, hiszen az intézmény a jelenlegi rendszerben inkább kiegészíti az iskola által alkalmazott minöségellenörzö folyamatokat és mechanizmusokat.
\end{abstract}

Hollandiában az oktatás minőségének ellenőrzése elsősorban a Holland Oktatási Felügyelöség (Inspectie van het Onderwijs) feladata, amely 1801 óta létezik, de az elmúlt időszakban kiemelt szerepet tölt be az oktatási rendszer fejlesztésében.

\section{A Felügyelőség feladatai, kötelezettségei, szerepei}

Az elmúlt húsz év holland oktatáspolitikájában két fontos irányvonal figyelhető meg. Egyrészt egyre nagyobb az igény az oktatáshoz kapcsolódó teljesítményelvárások és sztenderdek meghatározására és érvényesítésére, másrészt az országos szabályozás csökkenésével az oktatási intézmények autonómiája és felelőssége folyamatosan nő saját politikájuk és gyakorlatuk kialakításában.

Az Oktatási Felügyelöség jelenlegi müködésének jogalapja a 2002-ben életbelépett Oktatási Felügyeletről szóló törvény (holland rövidítése: $\mathrm{WOT}^{1}$ ), amely a fenti két irányvonal egyensúlyának megteremtésére törekszik: „A Felügyelőség szerepe, hogy értékelje és ösztönözze az oktatás minőségét, hogy tájékoztasson minden érdekelt felet az oktatás színvonaláról általában és egyes intézményekhez kötődően is".

A törvény egyik legfontosabb következménye, hogy az oktatás minőségének felelössége elsősorban magáé az iskoláé. Az iskola dönt a minőség értékelésének és ellenőrzésének céljairól (az országos kereteken belül), szervezeti formáiról, a mód-

\footnotetext{
${ }^{1}$ Wet op het Onderwijstoezicht (WOT)
} 
szerekről, a felhasznált anyagokról és a pedagógiai elvekről. A törvény arra kötelezi a Felügyelőséget, hogy időszakosan értékelést készítsen minden oktatási intézményről.

2008 óta a Felügyelőség az összegyüjtött információ és adatok alapján évente „ „kockázat alapú" ellenőrzések segítségével dönti el, hogy mely iskolákban tart ellenörzést, és melyek azok, amelyek megbízhatóan magas színvonalú oktatást nyújtanak. Ha az elemzés során nem merülnek fel kockázatok, akkor a felügyelöség a könnyebb (az úgynevezett ,alap”) ellenőrzési rendszert alkalmazza. Azokat az iskolákat, amelyek müködése nem felel meg az országos szabályozásnak, figyelmeztetik, s a Felügyelöség felhívja az iskola vezetőségének figyelmét arra, hogy mely területen, hogyan érhetnek el minőségi javulást. Amennyiben egy iskolában súlyos hiányosságok merülnek fel, a Felügyelőség intenzívebb felügyeleti rendszert alkalmaz, és végül jelentést tesz az oktatási miniszternek az iskoláról (Ehren és Honingh, 2011).

Az Oktatási Felügyeleti Törvény (WOT) meghatározza azokat a minöségi szempontokat, amelyek alapján a Felügyelőség elkészíti a jelentését, de az ezekhez kapcsolódó minőségi mutatók kidolgozását, az oktatási szektorral egyeztetett formában, a Felügyelőségre bízza. Az iskolák által kötelezően elkészítendő éves jelentés például a külső értékelés egyik fontos kiindulópontja a Felügyelőség számára.

Az elmúlt évtizedekben a felügyeleti rendszer meglehetősen központosított volt, erős interszubjektivitás és közös ellenőrzési keretek jellemezték. Ez az irányzat a hetvenes évek második felében indult és a kilencvenes években megerösödött. Mivel azonban az oktatási kormányzat elsődleges törekvése a dereguláció és az iskolák autonómiájának növelése volt, a Felügyelöség tevékenységének hangsúlya hamarosan áttevődött a jogok érvényesítéséről az iskolák eredményessége és más minőségi szempontok alapján történő szabályozásra. Ezt támasztja alá az a tény is, hogy a Felügyelöség iskolaértékelö eszközei, amelyeket nem szabályoz törvény, az oktatási szektor szereplöinek kölcsönös egyetértésével, országos konszenzus eredményeképpen alakulnak ki.

1998 óta a Felügyelőség iskolaértékelési jelentései, amelyekhez korábban csak az iskola és a miniszter férhetett hozzá, nyilvánosak. Minden egyes iskolaértékelés megtalálható a Felügyelőség honlapján ${ }^{2}$, így tehát az iskolák minőségére vonatkozó információhoz bárki hozzáférhet.

A Felügyelöség küldetésnyilatkozata a következőképpen határozza meg a fő célokat:

„Hatékony felügyelet a jobb oktatásért”. A Felügyelöség:

- a minőség fenntartására és javítására ösztönzi az oktatási intézményeket;

- ellenőrzi az oktatás minőségét az egyes intézményekben és az oktatási rendszeren belül egész Hollandiában;

\footnotetext{
${ }^{2}$ www.onderwijsinspectie.nl
} 
- hozzáférhető módon kommunikál minden célcsoporttal és az érdekelt felekkel;

- nyilvános jelentéseket készít (The Inspectorate of Education in the Netherlands, 2012, 10. o.).

\section{Az iskolák értékelése}

A Felügyelőség általános iskolákban, középiskolákban, szakközépiskolákban, szakiskolákban, a felnőtt oktatásban és a gyógypedagógiai intézményekben folytat ellenörzéseket. 2010-ben az ellenőrzések száma a következő volt: 7584 általános iskolákban és speciális alapfokú oktatásban, 2781 középiskolákban, 627 gyógypedagógiai intézményekben és 8541 szakközép- vagy szakiskolában, illetve a felnőttoktatásban (The Inspectorate of Education in the Netherlands, 2012, 12. o.).

Ahogy korábban említettük a Felügyelöség 2007 óta alkalmazza a kockázat alapú ellenőrzéseket. Ennek a rendszernek legfőbb célja, hogy egyrészt csökkentse az ellenőrzés által okozott kellemetlenségeket az iskoláknak, másrészt pedig növelje az ellenőrzések hatékonyságát. A Felügyelőség a jó minőségi oktatást adó iskolákat (ahol nem azonosítottak kockázatokat) azzal ,jutalmazza”, hogy az ellenőrzések száma itt jelentősen kevesebb, ugyanakkor a kockázatosnak talált iskolákban megpróbálja megteremteni a gyors javulás lehetőségeit.

Amennyiben a Felügyelőség a kockázat alapú ellenőrzés alapján úgy dönt, hogy meglátogat egy iskolát, akkor minőségi ellenőrzést végzenek. A teljes minőségi ellenőrzés során az alább felsorolt főbb minőségi kritériumokat vizsgálják, amelyekhez további részletes mutatókat dolgoztak ki. A minőségi kritériumok külön keretrendszert alkotnak az egyes oktatási szektorokra vonatkozóan. Fontos megjegyezni, hogy a minőségi ellenőrzés négy évben egyszer azokban az iskolákban is megtörténik, ahol nem találnak kockázatokat, illetve, hogy ezen kívül létezik még „téma szerinti" ellenőrzés, illetve adatgyüjtés az éves jelentéshez.

A minőségi kritériumok az egyes oktatási szektorokra vonatkozóan a következők.

Általános- és középiskolára vonatkozóan:

1. A tanulók eredményei a tanulói populáció jellemzőinek megfelelően elvárható szinten vannak.

2. A felhasznált tantervek felkészítik a tanulókat a továbbtanulásra és a társadalmi létre.

3. A tanár elegendő időt ad a diákoknak, hogy elsajátítsák a tananyagot.

4. Az iskolai légkört a biztonság és a tiszteletteljes interakció jellemzi.

5. A tanárok világos magyarázatokat adnak, hatékonyan szervezik saját oktatási tevékenységüket, és bevonják a diákokat a tanulási folyamatba. 
6. A tanárok úgy adaptálják, igazítják a tantervet, az oktatást, illetve a tanulásra és a tanításra fordított időt, hogy alkalmazkodni tudjanak a tanulók közötti fejlődési különbségekhez.

7. A tanárok szisztematikusan ellenőrzik a tanulók haladását. Az iskola úgy irányítja a tanulókat, hogy teret enged a saját képességeik szerinti fejlödésnek.

8. Külön gondosodnak azokról a tanulókról, akik erre rászorulnak.

9. Az iskolán belül működik saját minőségellenőrzési rendszer.

Szak- és szakközépiskolákra vonatkozóan:

1. Program: a program felépítése következetes, és lehetőségeket kínál a tanulók közötti különbségtételre.

2. Tanulási folyamat: a tanítás hatékony és ösztönzö, a környezet tiszteletteljesen biztonságos; minőségi tanárok alkalmazására van lehetőség.

3. Irányítás, segítség: a tanulók megfelelő irányítást és szociális segítséget kapnak iskolai karrierjük során.

4. Tanulás munkahelyi helyzetben.

5. Vizsgák és bizonyítványok.

6. Eredmények: az intézmény (szervezeti egység) megfelelő eredményt ér el a szakközépiskolai képzésben: az intézmény (szervezeti egység) felismeri a belső sikert.

7. Minőség vizsgálat.

8. Jogi követelmények: a jogi követelmények teljesülnek.

9. A finanszírozás folyamatos biztosítása.

Gyógypedagógiai intézményekre vonatkozóan:

1. Az iskola szisztematikusan gondoskodik az oktatás minőségének megőrzéséről és annak javításáról.

2. A gondoskodás és a minőség feltételei adottak az iskolában.

3. Az iskolában a tanulói gondoskodás ciklikus rendszere müködik.

4. Az iskola megfelelő irányítást és támogatást biztosít a tanulók számára.

5. A tanterv felkészíti a tanulókat a továbbtanulásra, vagy az iskola utáni életre, munkára, szabadidő eltöltésre.

6. A tanulók elegendő időt kapnak a tananyag elsajátítására.

7. A csoport tagjai úgy kezelik a speciális igényeket, hogy közben biztonságos és motiváló környezetet biztosítanak.

8. A tanárok úgy alkalmazzák a speciális igények szerinti módszereket, hogy azok támogassák a tanulók fejlődését.

9. A tanulók aktív és önálló szerepet játszanak a tanítási folyamatban. 
10. Az iskola légköre biztonságos és támogató.

11. A tanulók eredményei elérik a tanulók jellemzői szerint elvárható minimális szintet.

(The Inspectorate of Education in the Netherlands, 2012, 13. o.).

\section{Az ellenőrzés folyamata}

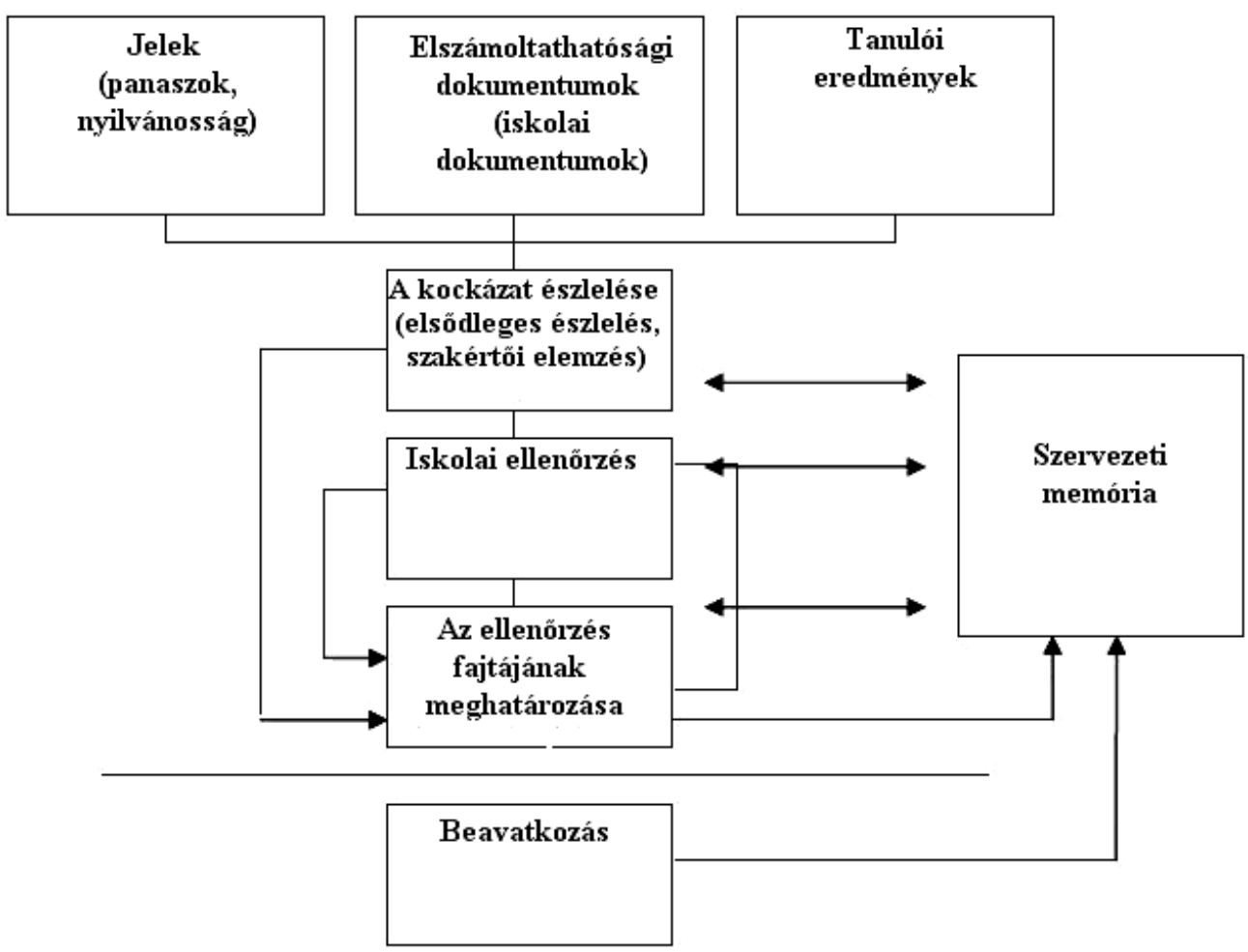

1. ábra: Az ellenőrzés folyamata. (The Inspectorate of Education in the Netherlands, 2012, 16. o.)

A rendszer tulajdonképpen három elemen nyugszik, amelyek mind információt adnak a kockázatokról a jeleken, az elszámoltathatósági dokumentumokon és a tanulói eredményeken keresztül.

\section{Jelek}

A Felügyelőség a kockázatelemzéshez ,jeleket” használ. A jelek olyanfajta történések az iskolában, amelyek a tanulói teljesítmény romlását eredményezhetik a jö- 
vőben, például panaszok (a tanulók, szülők, tanárok vagy más szereplők részéről), cikkek az újságokban vagy az interneten, vagy a témaszerinti ellenőrzés eredményei. Ezek a jelek általában naprakészebb információt nyújtanak, mint a tanulói eredmények vagy a dokumentumok.

\section{Elszámoltathatósági dokumentumok}

2008 óta minden iskolaszék köteles évente beadni egy olyan dokumentumot, amely nemcsak a pénzügyi jelentést tartalmazza, hanem az iskola minőségi eredményeinek leírását is. Ezeket a dokumentumokat egy integrált kockázati modell alapján elemzik.

\section{Tanulói eredmények}

A Felügyelöség minden évben minden iskolából összegyüjti a tanulók eredményeire vonatkozó információkat. Ezeknek az eredményeknek kb. 80 százalékát független tesztelő vagy vizsgáztató intézmények bocsátják rendelkezésre, a maradékot pedig maguk az iskolák. Minél alacsonyabbak az eredmények, annál magasabb a kiszámított kockázat.

\section{Elsődleges észlelés}

A fenti három elem felügyeletét nevezik elsődleges észlelésnek. Ez azt jelenti, hogy részletesen elemzik az adatokat és megállapítják a kockázati szintet. A kockázatmentes iskolák esetében - amint fent már említettük - az ,alap típusú” ellenőrzést alkalmazzák, ami azt jelenti, hogy bíznak abban, hogy az iskola megfelelően teljesít majd a következő kockázatfelmérésnél is. Amennyiben kockázatot azonosítottak, akkor további vizsgálatot kezdeményeznek.

\section{Szakértői elemzés}

Ez a további vizsgálat ,,desk research” jellegü, vagyis a Felügyelöség szervezeti memóriájában fellelhetö, illetve nyilvánosan hozzáférhető információ alapján történik (például az iskola honlapja). Ez alapján kiderülhet, hogy tulajdonképpen mégis minden rendben van, vagy pedig a felmerülő gyanú vagy probléma megerősítést nyer. Utóbbi esetben a vizsgálat folytatódik a probléma azonosításával és leírásával.

\section{Iskolai ellenörzés}

Az iskolai ellenőrzés az iskolaszékkel való kapcsolatfelvétellel kezdődik, de maga a vizsgálat az iskolában folyik. Az iskolaszékkel folyatatott interjú alapján kiderül, hogy tudnak-e a felmerülő problémákról és képesek-e megoldani azokat. Ilyenkor a legtöbb esetben a felügyelö minőségi ellenőrzést javasol, amely a kockázatok fi- 
gyelembevételével jelöli meg a minőségi szempontokat. Az ellenőrzést általában egy hónappal elöre bejelentik.

A minőségi ellenőrzés végén jelentés készül, amely azonosítja az oktatás minőségével kapcsolatos problémákat, és a törvényi elöírások betartását. A jelentésben meghatározzák az ellenőrzés fajtáját is.

\section{Az ellenörzés fajtája}

Ahogy korábban említettük az ellenőrzés lehet „alap típusú”, ami azt jelenti, hogy az iskola (az ellenőrzés után) megfelel a sztenderdeknek, vagy megfelelőnek értékelték. Amennyiben problémák merültek fel, az iskolában egyedi ellenőrzést folytatnak. Jelentés készül, amelyben a problémák leírásán kívül szerepelnek azok a döntések és megegyezések az iskolaszékkel, amelyek a minőség javítását célozzák, illetve meghatározzák a határidőket és a folyamat ellenőrzését is. Az ellenőrzés fajtája központi pillére a kockázatalapú felügyeletnek.

\section{Beavatkozás}

A felügyelet végső célja természetesen az oktatás minőségének javítása. A beavatkozási szakaszban az iskolának lépéseket kell tennie a hiányosságok felszámolására, amelyeket a Felügyelőség ellenőriz. Ha az iskolának nem sikerül javítania a helyzeten a Felügyelőség további nyomást gyakorolhat rá, illetve szankciókat alkalmazhat. Ilyenkor megint kiválasztják a legmegfelelőbb ellenőrzési formát. Amennyiben minden lényeges problémát megoldottak, az iskola ismét alap típusú ellenőrzést kaphat.

\section{Az ellenőrzés módszerei}

- Kérdöivek, kérések az iskoláknak: amennyiben egy általános iskola nem bocsátotta rendelkezésre tanulóinak eredményét, a felügyelőség felszólítja erre. Az oktatás többi szektorában erre nincs szükség, mert az eredményeket automatikusan beküldik. Emellett az iskoláknak kötelező évente rendelkezésre bocsátani az elszámoltathatósági dokumentumokat.

- Kapcsolat az iskolaszékekkel: az iskolaszék felelős az oktatás minőségének biztosításáert, azért a Felügyelőség először velük veszi fel a kapcsolatot.

- Interjúk diákokkal: elsősorban a biztonságról, a támogatásról, az oktatással töltött időről, az oktatás módszereiről, az autonóm tanulásról, az iskola légköréről, a tanárok odafigyeléséről stb.

- Interjúk tanárokkal: a minőségi ellenőrzés bármely szempontjáról.

- Interjúk az iskola nem tanár alkalmazottaival: elsősorban szakközépiskolákban és gyógypedagógiai intézményekben fordul elö.

- Interjúk a szülökkel: néha a szülőket a diákokhoz hasonló témakörökben kérdezik meg, illetve részvételükröl az iskolai életben. 
- Megfigyelések: a minőségi ellenőrzés során a felügyelők megfigyelnek órákat és iskolai eseményeket, az iskolai életet a tornateremben, a könyvtárban, a laborokban, stb.

- Vizsgák és tesztek: a középiskolai tanulók esetében a Felügyelöség elemzi mind az iskola maga által kidolgozott, mind a központi, országos tesztek eredményeit, amelyeket két intézmény állít elö (a CEVO, a középiskolai vizsgák országos bizottsága, illetve a CITO, az oktatás mérésének országos intézete). Fontos megjegyezni, hogy a középiskola elvégzésének értékelése (az érettségi vizsgának megfelelő vizsga) is minden tantárgyból két részből áll: az iskolai és az országos vizsgából. Ez jól kifejezi az iskolák autonómiája és az állam minőségi garanciájának egyensúlyát.

A Felügyelöség szintén ellenőrzi a vizsgák eljárásait a megbízhatóság, az elöírt tantárgyi célok, a minőség és a szint szempontjából. Ezen túl a Felügyelöség figyeli az iskolai vizsgapontszám és az országos vizsgaeredmény közötti eltéréseket is. Ha az iskolai vizsgaeredmények lényegesen magasabbak, mint az országos vizsgarész eredményei, akkor ez a kockázat egyik jele lehet.

A tantestület, illetve a tanárok munkájának értékelése nem külön feladata a $\mathrm{Fel}$ ügyelöségnek, vagyis nem dönthet az iskolai személyzet elbocsátása, vagy elöléptetése ügyében. Ilyenfajta döntéseket csak az iskolaszék hozhat. Ha az iskolában teljes ellenőrzés folyik, akkor a tanárokat megfigyelik, de az értékelés csak a „tanítás minőségére általában”, vagy a ,vezetőség munkájára általában” vonatkozhat.

\section{Az iskola minőségére vonatkozó jelentések}

A Felügyelöség által jelenleg használt kockázat elemző modellben a „közlekedési lámpa" elv érvényesül. A kockázatok észlelésének három fokozata létezik: nincs kockázat (zöld), esetleges kockázatok (sárga) vagy valószínủ kockázatok (piros). Általában a „nem kielégítő”, gyenge”, „megfelelő” és ,jó” kifejezéseket használják a mutatók értékelésére.

A 2009/10-es tanévben a következő arányban fordultak elő a különböző megítélések: az általános iskolák közül 1\% nem kielégítő, $6 \%$ gyenge, $93 \%$ megfelelö/jó; a középiskoláknál 1,1\% nagyon gyenge, $10 \%$ gyenge, $88,9 \%$ megfelelö/jó (The Inspectorate of Education in the Netherlands, 2012, 19. o.).

\section{A felügyelők toborzása, képzése}

Ahhoz, hogy valaki felügyelő legyen egyetemi diploma vagy azzal egyenértékü képesítés szükséges, széles körü tapasztalat és tudás az oktatás területén, illetve lehetőleg tanítási és vezetői gyakorlat. Nincs kifejezett felvételi vizsga, de nemrég értékelő eljárásokat vezettek be, amelynek főbb szempontjai az íráskészség, érté- 
kelési és interjú készségek. Ennek következtében a felügyelők életkora általában viszonylag magas volt, és ez „utolsó munkahelynek” számított, ez azonban az elmúlt tíz évben megváltozott. Ma az átlagéletkor 35 év, és már gyakoribb, hogy a felügyelök később iskolaigazgatókként vagy iskolaszékek vezetőjeként vállalnak állást.

Az új felügyelők négy hónapos képzésen vesznek részt. A képzés általában csoportosan történik, és részben elméleti részben gyakorlati felkészítést ad, amelynek során az új felügyelők megfigyelőként vesznek részt az iskolai megfigyeléseken.

\section{Tanulságok, értékelés}

A holland Oktatási Felügyelöség müködésének talán legérdekesebb jellemzője az a szerkezeti és attitüdbeli változás, amely 2008 után bekövetkezett. Azelött minden iskolát négy évenként ellenőriztek, azóta azonban csak az oktatás színvonalának csökkenésének kockázatát felvető iskoláknál tartanak ellenőrzést. A változás másik fő eleme, hogy az iskolaigazgatók helyett az iskolaszék az ellenőrzések fö kapcsolattartója és egyben alanya is.

A felügyeleti módszerek e változásai elsősorban a Holland Kulturális és Oktatási Minisztérium filozófiáját tükrözik azzal kapcsolatban, hogy miként kell egy iskolát vezetni és ellenőrizni. Ezt a filozófiát több kormányzati dokumentumban is megfogalmazták, és általában a 2010-ben keletkezett „Jó oktatás, jó kormányzás” törvényhez kötik (Ehren és Honingh, 2011, 1. o.).

A jó kormányzás feltételezi, hogy az iskolák képesek megbizhatóan ellenőrizni, értékelni és javitani az oktatás színvonalát anélkül, hogy az Oktatási Felügyelöség kívülről ellenőrizné ezt a folyamatot. Az iskolaszékektől elvárható, hogy elszámoltathatóak legyenek az érintettek, elsősorban a szülők és a diákok felé. Rendelkezniük kell olyan minőségbiztosítási rendszerrel, amely beszámol az érintetteknek, emellett fenntartja és javítja az oktatás színvonalát. Létezik ugyanakkor egy belső felügyelő bizottság is, amely az iskolaszékek müködését ellenőrzi. A minőségbiztositási rendszer, az érintettek számára nyújtott beszámolók és a belső ellenőrzés együtt várhatóan biztosítja a szükséges fékek és ellensúlyok horizontális struktúráját az iskolák színvonalának javításához.

Ebben a rendszerben a Felügyelőség szerepe is megváltozott, inkább kiegészíti azokat a mechanizmusokat és folyamatokat, amelyeket az iskola alkalmaz. A Felügyelőség új szerepét a következő hat alapelv írja le a legjobban: független, átlátható, szakmai, szelektív, szigorú és együttmüködő (Ehren és Honingh, 2011, 3. o.).

Azokban az esetekben azonban, amikor az iskolák nem alkalmazzák és valósítják meg az említett mechanizmusokat és elveket, vagy ahol az eljárások nem vezetnek a megfelelö eredményekhez az Oktatási és Kulturális Minisztériumnak be kell avatkoznia. Az új törvényi szabályozás lehetőséget ad további beavatkozásra, illetve 
szankciók bevezetésére, ha az iskolában a tanulói eredmények (különösen matematikából, az olvasás és az íráskészség területén) nem érik el az elvárt átlagot.

Wolf és Verkroost (2011) részletesen megvizsgálták a jelenlegi iskolafelügyeleti rendszert a tudományos irodalom és az iskolák nyilvános adatai, eredményei alapján. Annak ellenére, hogy az adatok száma még nem teszi lehetővé messzemenő következtetések levonását, a gyakorlatban azt tapasztalták, hogy a kockázatalapú ellenőrzés bevezetése óta a nem megfelelő (nagyon gyenge) iskolák száma csökkent. Az elmúlt évtizedben ez a szám évről évre növekedett, majd az új rendszer bevezetésekor ingadozni kezdett. A további csökkenés jelentheti az új ellenörzési forma hatékonyságát. A másik érdekes eredmény szerint a nagyon gyengén teljesítő iskolák szinte mindig javuló tendenciát mutatnak, ami szintén annak a jele lehet, hogy az ellenőrzés jól müködik (Wolf és Verkroost, 2011, 15. o.).

Szintén egyértelmüen megállapítható, hogy az arányos és szelektiv ellenörzés lényegesen kedvezöbb az iskolák és a Felügyelőség számára is. Az iskolák esetében az ellenőrzések terhe jóval kisebb, a Felügyelőség munkája pedig jóval hatékonyabb. A szerzők szerint még korai lenne annak eldöntése, hogy az ellenőrzések egésze ebben a modellben hatékonyabb-e.

Az értékelő tanulmány alapján az egyetlen dolog, ami még nem müködik optimálisan a holland oktatási felügyelet területén a fékek és az ellensúlyok rendszere. Az oktatás minősége nem minden iskolában éri el a sztenderdet, és a belső ellenőrzés, illetve az érintettek horizontális elszámoltathatósága még gyerekcipőben jár. Ez az jelenti, hogy jelenleg még több függ a Felügyelet minőségellenőrzési eljárásaitól, mint ami ideális lenne. A minőségbiztosítás és a minőség javítása területén az iskolaszékek aktívabb szerepvállalására lenne szükség. Ugyanez elmondható az érintettekkel (szülök, diákok) folyatott párbeszédre is. Amikor a Felügyelőség hozzájárul az érintettekkel való kapcsolathoz, akkor a szülők és a diákok aktívabban ösztönzik az iskolaszéket a további minőségjavításra.

A rendszer tehát a központi ellenőrzés és a helyi autonómia kényes egyensúlyának figyelembevételével alapvetően hatékonyan müködik, a legfőbb nehézséget nyilvánvalóan a külső és belső ellenőrzés optimális arányának kialakítása okozza.

\section{Irodalom}

Amelsvoort, G. et al. (2006): The supervision of education in the Netherlands. SICI Newsletter, No. 32. 3-12.

Effective School Self-Evalaution (ESSE), 2003. http://www.edubcn.cat/rcs_gene/extra/05_pla_de_formacio/direccions/primaria/bloc1/ 1_avaluacio/plugin-essereport.pdf

Ehren, M. C. M. - Leeuw, F. L. - Scheerens, J. (2005): On the Impact of the Dutch Educational Supervision. Act Analyzing Assumptions Concerning the Inspection of Primary Education. American Journal of Evaluation, No. 1. 60-76. 
Ehren, M. C. M. - Honingh, M. E. (2011): Risk-based school inspections in the Netherlands: A critical reflection on intended effects and causal mechanisms. Studies in Educational Evaluation, No. 4. 239-248.

The Inspectorate of Education in the Netherlands, 2012.

The Netherlands Inspectorate of Education (2011): The state of education in the Netherlands. Education Report 2009/2010. The Netherlands Inspectorate of Education, Utrecht.

The Netherlands Inspectorate of Education (2011): Meerjarenbeleidsplan 2010-2014 (Long term policy plan). The Netherlands Inspectorate of Education, Utrecht.

Wolf, I. F. - Verkroost, J. J. H. (2011): Summary evaluation of theory and practice of risk based school inspections in the Netherlands. The Netherlands Inspectorate of Education, Utrecht.

http://www.sici-inspectorates.eu/getattachment/ee4990f8-363d-4437-8548-

f0c0d8756499 